Article

\title{
What Governance? The Role of Public and Private Stakeholders in Water Supply Management in Mediterranean Coastal Tourist Destinations: The Case of the Costa Brava
}

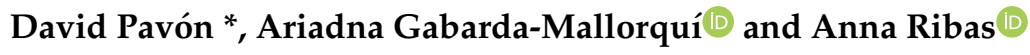 \\ Department of Geography, Faculty of Arts, University of Girona, Plaça Ferrater i Móra 1, 17004 Girona, Spain; \\ ariadna.gabarda@udg.edu (A.G.-M.); anna.ribas@udg.edu (A.R.) \\ * Correspondence: david.pavon@udg.edu; Tel.: +34-972-418-717
}

Received: 27 September 2018; Accepted: 23 November 2018; Published: 30 November 2018

\begin{abstract}
A large number of services have been privatized in recent decades, leaving less responsibility for public administration management. This trend has resulted in an intense debate on which services should be guaranteed and the equity and efficiency criteria that should be applied in their provision. The move to privatize the potable water supply in one of the main international tourist destinations - the Costa Brava (Spain)—can be included within this context. Our aim is to identify and characterize the main water governance systems on the Costa Brava in order to explore the different forms of water supply governance. To this end, an analysis has been carried out to explain the different interrelations between the expansion of tourism and the management of water supply infrastructures. The insufficient technical and financial resources of local and regional governments encourage the entry of private initiatives. In this process, we must also take into account the consolidation of a larger customer market linked to tourism development. Our main conclusion is that water governance models in coastal tourist destinations such as these are determined not only by territorial needs and the lack of technical capacity, but also by the emergence of business opportunities in the private sector.
\end{abstract}

Keywords: Costa Brava; tourism development; water governance; water supply

\section{Introduction}

In general terms, the environmental deterioration of water resources is related to global environmental change [1] due, amongst others factors, to the construction of hydraulic infrastructures [2] and the increased demand for water resulting from both economic and demographic growth [3] and the rapid spread of tourism [4]. Specifically, the latter has given rise to "complex and interrelated changes to the economy, culture, the environment and policies" [5]. In respect of this, the multiple economic benefits generated by tourism are unquestionable, both at a local and regional level. However, the environmental, territorial and social impacts derived from tourism development [6,7] cannot be ignored. Among these, one of the most significant impacts is the overexploitation of water resources derived from increased water consumption related to tourism activities, which undoubtedly affects both water quality and quantity [8]. With regard to this, it is important to emphasize that tourism depends to a large extent on the availability of water, and this generates significant tensions as tourist activities reach their height in destinations such as the Mediterranean, where water is such a scarce commodity [9].

Initially, prior to the tourism boom, water governance was often solely in the hands of a public administrator, who was the regulator of the entire system, in terms of regulation, investment and 
infrastructure management. However, from the second half of the 20th century onwards, due to the progressive arrival of tourists in coastal areas of the Mediterranean, many destinations were forced to adapt their supply systems to deal with an increase in water demand. In many cases, the search for new water sources and the emergence of health regulations for consumption, among other factors, have made water management more complicated. Thus, growing complexity in the supply service has also led to changes in the governance of the resource. In order to guarantee the water supply without jeopardizing the environmental quality of water resources and minimizing confrontation between different users, the public sector is no longer the only actor that participates in its governance. Rather, other agents have emerged, such as private companies, users and/or non-state organizations [10-12]. Therefore, although this change has mainly been motivated by the need to satisfy an increasing number of users, there are other factors that explain the emergence of new actors in the governance of the resource in numerous tourist destinations in the Mediterranean.

Water governance has become a key element in the Mediterranean coastal area due to the need to manage a scarce resource that is disputed among different users. The United Nations Development Programme's Water Governance Facility (2013) suggested that governance should address, among other aspects, principles such as equity and efficiency in the allocation and distribution of water resources, its administration and management and the need to balance its exploitation between socioeconomic activities and ecosystems [13]. Dealing with current and future challenges requires strong governance that sets out measurable goals, with predetermined deadlines and on a scale appropriate to the distribution of tasks among the different actors involved. Thus, questions arise not only regarding what needs to be done but also who does what, for whom and how [14].

The aim of this study is to identify the main water governance systems that have been implemented on the Costa Brava (Spain) during the 20th century and the first years of the 21st century. In this way, we wish to explore the territorial, socioeconomic and environmental changes that have undoubtedly motivated the appearance of new scenarios and new actors in said systems. To do this, a retrospective analysis has been carried out to explain the different synergies between tourism development and management in water supply infrastructures. Meanwhile, we expect to explain the form of water governance in the area of study, its socioeconomic and territorial realities, the technical capacity involved in its management, and lastly, the reasons that have led to the private sector becoming one of the main actors involved in water supply governance.

\section{Water Governance. Public versus Private Management}

Urban Political Ecology (UPE) and water metabolism research have provided science with a theoretical framework that allows us to explore the relationships between the different social, political, economic and natural elements that interact in urban environments [15]. In fact, water management refers not only to the technical but also the political, social and organizational aspects of water supply and sanitation [16]. Adopting a UPE approach to analyse water flows in a given territorial area allows us, then, to determine the main interrelating elements of socioeconomic, environmental and institutional systems [17]. It is these relationships that define the term hydrosocial cycle, a concept that extends the hydrological cycle and adapts it to the UPE framework, thus incorporating the anthropic influence and turning it into a hybrid amalgam of nature (water) and society [18]. In fact, the relationship between water and society is one of the main focuses of research into issues such as water shortages, river basin management and privatization processes in water management in urban areas today [17]. In this regard, and in reference to the latter, research on governance allows us to explore changes and trends in power relations around water management, understanding governance as an analytical concept that allows us to examine how the different agents involved, such as a state government and / or the non-state agents involved in water management (private sector, non-governmental organizations, neighbourhood associations and/or the local community) [19] negotiate and agree certain objectives in order to guarantee the water needs of the population [20]. Complementary it resolve conflicts of an organizational or social nature at the national and/or 
international level [21]. When we talk of water governance today, we consider all those political, economic, social and administrative systems that take place in the management of water resources and the water supply on different scales [22]. In fact, water management refers not only to the technical but also the political, social and organizational aspects of water supply and sanitation [16].

Water governance in a particular region is not static but rather continually under the influence of dynamic processes caused by population, urban and economic changes, and even more complex changes related to globalization, technological advances (desalination and regeneration) and perceptions regarding water and social attitudes towards it [23]. One of the forces of change that affects water management and therefore explains governance is the interaction between the public and private entities in charge of resource management [19]. Water is a resource that must respond to vital economic, social and environmental needs; it requires a strong initial capital investment and involves high maintenance costs [24]. Therefore, alternation between public and private water management has been the centre of debate in the water sector, especially regarding the best option to prevent the collapse of the system and achieve efficient distribution of the resource that guarantees the needs of the population are met. Throughout the history of urban water supply, public management has been the most common form of administration [25]. However, the wave of industrial deregulation that took place during the 1970s in the English-speaking world [24] and during the 1980s in the United States [25] encouraged the private sector to increase its participation in water management, a common practice in many developed countries today. For example, taking data from 2007, the private sector supplied water to more than 70\% of the population in France and the United Kingdom; between 50 and 70\% in the Czech Republic; and between 30 and 50\% in Greece, Italy and Spain [26]. In the latter case, Spain, it is worth mentioning how many of the regions on its Mediterranean coast have become a paradigm of privatization for the different parts of the water cycle. Although we often talk about quite different socioterritorial realities throughout the Spanish Mediterranean arc, the political and economic context has been key to understanding many privatization processes falling into the hands of a few large companies [27]. The uneven distribution of water resources along the coast, water shortages and the urban development boom deriving, among other factors, from tourism development have resulted in large multinational companies with significant capital linked to construction being at the forefront of water supply management in the region today.

The privatization of potable water management presents itself as an option when the aim is maximum efficiency and cost reduction. Research has shown that water supply services are often privatized due to restrictions on public budgets and the will to achieve the highest possible efficiency of the service, rather than for political or ideological reasons [28]. However, a privatization process often involves a change of focus in the decision making and/or management systems inherent in governance of the resource. Thus, the private sale of water as an economic asset implies changing the principles of ethics, from social equity to economic equity, and the criteria of infrastructure construction, from ensuring supply to cost recovery [29]. In addition, the process of privatizing urban water supply management has often led to negative changes in the working conditions of the service itself such as layoffs, salary freezes and/or social benefit cuts, among others [27]. In this regard, the re-municipalization of the service emerges as an alternative to possible private sector management failures [24], although it can also represent a clear example of the desire of local politicians to gain more control over the water supply system [27] or a response to the many social movements opposing the privatization of water supply services [30]. These movements advocate municipalization to improve the environmental quality of water ecosystems and working conditions, and even to achieve a more democratic urban environment [27]. This is the case with large European cities such as Paris or Berlin, which have recently redesigned their water supply services [30]. Aside from this, public-private partnerships are also becoming increasingly more frequent in water management [31]. Mixed public/private companies in charge of the water supply service are based on an agreement between the public entity and one or more private companies, the latter being in charge of supply in accordance with objectives agreed between the two parties [32]. This type of collaboration between 
the public and private sectors has been employed in many cities and urban areas, leading to multiple economic and employment-related benefits, as well as improving the efficiency and quality of the service [33]. Finally, mention should also be made of new forms of water governance based on the community's management of the resource. The communal form of management emphasizes the moral and ethical distribution of the resource and is based on equity and solidarity among the different groups of users that comprise the community. In fact, community water management is a form of non-capitalist management and is more resilient in situations of scarcity and even more flexible in cases of reform to water use and/or ownership rights [34].

Water supply governance can take many forms and be under the control of public, private and/or communal management. The political and economic reality of a territory will therefore be expressed in how it manages the resource, meaning decision making is subject to the goals of the actor in control of the water supply.

\section{Materials and Methods}

As part of the methodology included in the research, we particularly took into account the water supply projects implemented by the 22 coastal municipalities of the Costa Brava since the beginning of the 20th century. These are part of the historical archives belonging to the Catalan Water Agency (regional water management authority) deposited in the National Archive of Catalonia (Sant Cugat del Vallès, Barcelona). The reasons that led the municipalities to develop their supply projects have been identified and analysed in accordance with these documents. Project reports, when preserved, usually specify the reasons for their having been commissioned, their background and how the works are expected to be funded and maintained. Likewise, they usually mention the individual towns' supply systems and sources until that date, the problems or insufficiencies that they had in that regard and what solutions they could adopt to resolve them. An interesting feature of Costa Brava municipalities is that in several cases they have preserved both the first projects from the beginning of the 20th century, which designed the initial water supply networks, and the projects from the 1950s and 1960s, implemented due to the deficiencies of those devised half a century before, when the social, economic and urban circumstances were very different. In addition to these documents, we have also analysed the period and the way in which private companies began to enter the business of supplying water to these tourist municipalities and progress since then. In order to determine the current distribution levels of these companies and their public, private or mixed ownership, we consulted press articles from local media and the database of the association 'Aigua és vida' (Water is life), which concerns itself with water policy in the region of Catalonia and the fact that the management of the integral water cycle is carried out by the public sector and with the participation of both the local authorities and civil society organizations.

\section{Study Area}

The Costa Brava is located in the north-east corner of the Iberian Peninsula and forms the northernmost Mediterranean coastline of Spain and specifically the region of Catalonia. The Costa Brava is $158 \mathrm{~km}$ in length and includes the entire coast of Girona province, with 22 municipalities from north to south, from the border with France to the boundary with Barcelona province. It has a surface area of $662 \mathrm{~km}^{2}$ and its registered population in 2016 was 243,102 inhabitants. If we relate these parameters to those of the province as a whole, although the municipalities of the Costa Brava only equate to $11.19 \%$ of its surface area, they account for $32.26 \%$ of its population. However, to this figure we must add the seasonal population, which in municipalities such as Tossa de Mar or Castell-Platja d'Aro can reach more than $80 \%$ of the resident population. According to 2017 data provided by the Statistical Institute of Catalonia, the 22 municipalities on the Costa Brava coast had 305,675 inhabitants including equivalent tourists. In terms of hydrography, the coastal zone of the Costa Brava includes the final stretch of different river basins. The most relevant of these are, from north to south, the Muga, the Fluvià, the Ter and the Tordera basins. 
The Costa Brava is undoubtedly one of the main international tourist destinations in the Mediterranean Basin and is of special interest to the object of this study, for three main reasons: the economic weight of its tourism sector, the urban development derived from tourist activities and the many challenges it faces with regard to water management. The Costa Brava began to develop as an international tourist hub during the fifties and sixties of the twentieth century and its long history as such means it is now consolidated as a tourist destination. Tourist activities have become the region's largest economic resource. According to Duro (2011) [35], tourism and its related activities accounted for $17.1 \%$ of the Costa Brava's gross domestic product in 2010 . The sector generated 46,000 jobs during the same year, making up $18.7 \%$ of the labour market. In terms of tourist accommodation capacity in the region in 2016, the region's 22 municipalities offered 501 hotels with 66,583 beds, 91 campsites with a capacity for 115,452 guests, and 41 rural tourism establishments with 390 beds. The four municipalities with most tourist establishments are Lloret de Mar, Tossa de Mar, Roses and Castell-Platja d'Aro; these four places alone accounted for $52.29 \%$ of the tourist accommodation and $74.72 \%$ of its beds in the same year. Given the socioeconomic weight of tourism throughout the Costa Brava, it is vitally important to determine and advance its ability to adapt to new climatic scenarios.

Although the Costa Brava is still a renowned international attraction, to remain so it faces important challenges in terms of environmental and socioeconomic management. One significant piece of data for understanding the impact of tourism development is residential expansion in terms of land urbanization (Figure 1). It is estimated that the urbanized surface area of the Costa Brava increased almost 8-fold during the second half of the 20th century, growing from 1149 hectares in 1957 to 8815 in 2003 [36]. A second challenge deriving from tourism development in the region has been a constant lack of water. Some problems of salinization in local water wells were already beginning to emerge in the 1950s and the first temporary solutions were contemplated to meet the needs of the resident and visitor populations. This fact has meant that the Costa Brava currently enjoys a significant diversity in both conventional (surface waters from rivers and aquifers) and non-conventional water supply sources (from desalination stations or regenerated water). The Costa Brava therefore represents a good case study due to the different strategies that have been followed to capture the water necessary for the region's socioeconomic development.

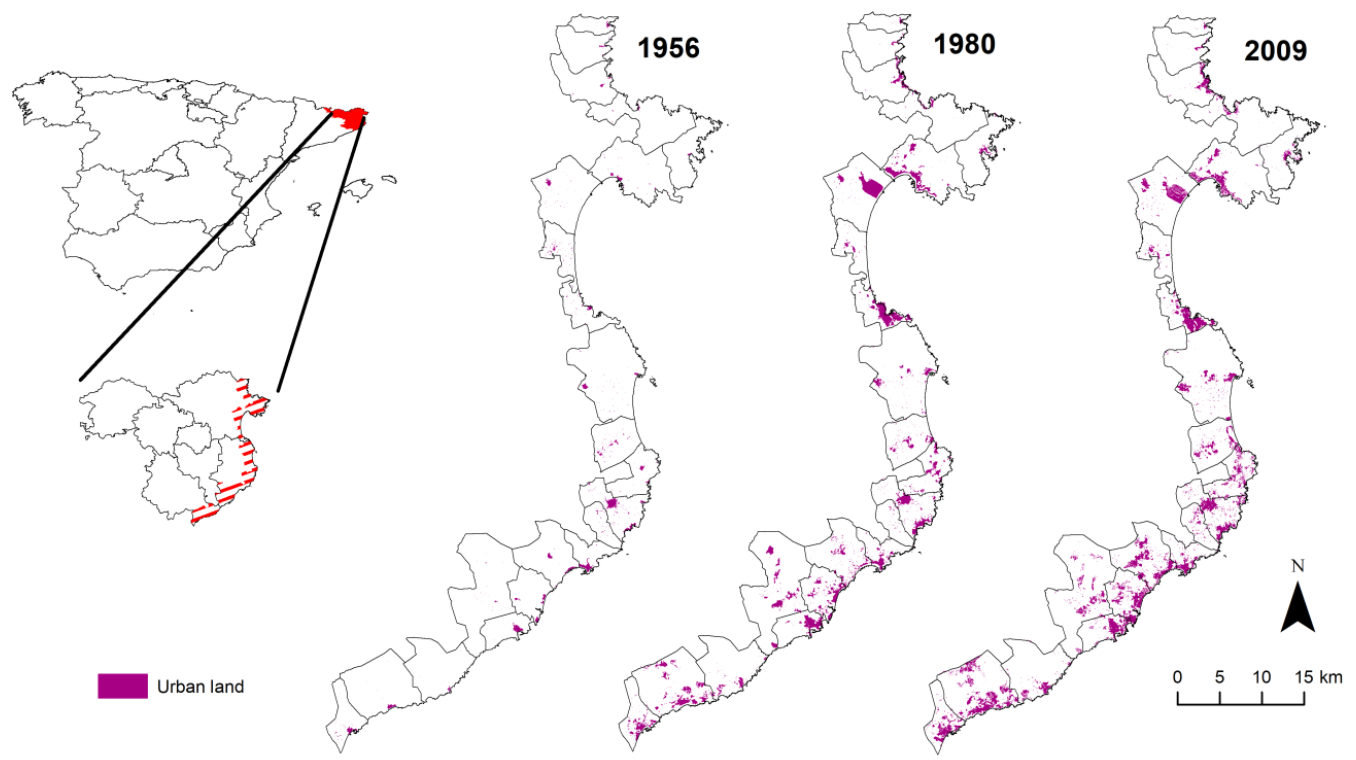

Figure 1. The municipalities of the Costa Brava and its urban growth (1956-2009). Source: [36].

\section{Historical Changes in Water Supply Systems on the Costa Brava Region}

As mentioned previously, adopting a UPE approach to analyse the water flows that occur in a territorial area allows us to identify the main elements connecting the socioeconomic, environmental 
and institutional systems [17]. It is precisely by focusing on these elements that interrelate the socioeconomic (mainly the tourism industry), environmental (the use of water resources and its environment) and institutional (administration and management) systems that we have been able to establish a three-stage period in the history of water being supplied to the Costa Brava. The first comprises its early history, from the end of the nineteenth century up to the 1950s, which is defined by the implementation of the first real technical projects; the second, from 1960 to 1980, is marked by the expansion of (mass) tourism; and the last, from 1980 onwards, is when water resources external to the Costa Brava began to be incorporated.

\subsection{The Early Days until the 1950s: The Emergence of the First Projects}

Up until the 1950s, all water resources were captured from numerous local underground aquifers near the population centres and managed by each of the municipalities, providing sufficient resources to meet urban water demands [37]. Prior to that date, progress in expanding the water supply network was not so much to cater to the urgent needs of large growth, but to guarantee sufficiently clean water and generate a still inexistent supply network within the urban centres. During the first third of the 20th century, these Costa Brava municipalities often did not have any running water to reach people's homes, but rather local residents had to go to public water sources, inside or outside the urban centre, to retrieve it themselves. Water was perceived as a means of transmitting infectious diseases such as cholera or typhus, which may even have deadly consequences. Therefore, there was an urgent need to implement technical projects, which were very much influenced by hygienist postulates to ensure the water was in an acceptable condition for health [38].

In Spain as a whole, moves were made to declare the supply of potable water to towns and cities a public service from the end of the nineteenth century onwards, it effectively being implemented in the early decades of the 20th century. The Public Works Act of 1877 outlined some issues related to the supply of water, which persisted during the first third of the twentieth century, including its declaration as a municipal public service. The Act made improving water cleanliness the responsibility of local councils. Starting in 1910, Spain defined a programme of actions for local councils to build their supply networks. The Royal Decree of 27 March 1914 awarded subsidies of over 25 million pesetas to help small towns with problems building their supply networks. In just over 10 years, more than 1000 municipalities throughout Spain received subsidies to implement this type of work [39].

The so-called Municipal Statute was approved in 1924, leading to the Regulation of Works, Services and Municipal Properties, which would introduce slight modifications to the powers held by local councils with regard to urban services. It was in this year that the supply of potable water was explicitly recognized as a public service. Particular aspects to be taken into account were the general application of the service, limits on fees and public quality control. By means of the aforementioned 1914 Royal Decree and the new one introduced on 9 June 1925, subsidies were established for water catchment and channelling [40]. Both Decrees established a minimum allowance of 50 litres per inhabitant per day. Several municipalities on the Costa Brava received these subsidies both to improve their local water catchments and to establish or consolidate their supply networks. This was the case of the technical supply projects drawn up in Blanes (1925), Roses (1926), Castelló d'Empúries (1927), Cadaqués (1929), Port de la Selva (1931) and Castell-Platja d'Aro (1937). In the case of Blanes, a 1925 text states [41]: 'The City of Blanes, with some 4950 inhabitants, supplies its population with nothing more than a scant flow of water from the nearby mines. [...] Blanes City Council, concerned about this extremely important Service, presents the attached project and request for the purpose, subject to the current regulations, especially that established by the R. D. of June 9 on State aid for works to supply potable water to towns and cities, of obtaining the Superior resolution so that the works can be built'. Throughout this stage, councils were either directly responsible for financing the works and their subsequent entry into service, or did so via municipal water companies. This is the case of the municipality of Blanes, which in November 1925 decided to create the public company 'Aigües de Blanes, S.A.' in order to build the potable water supply network and manage its subsequent use. In the case of Roses, the decision to municipalize 
the water service was submitted to a restricted popular vote on 9 November 1924, with all heads of households with "an open house maintained at their expense", men or women, able to vote. The result was clear: all 482 votes cast were in favour of the city council acquiring private concessions from various sources and obtaining credit to directly manage the service [42]. Following this, the relevant supply project was drafted.

\subsection{Water Supply and the Tourism Boom (1960-1980): Differentiating Between High-Level and Low-Level Supply Systems}

During much of the 1960s, a new generation of projects began to take shape in which the main concern was no longer the configuration of a potable water distribution network-often still inexistent in these towns-as in the preceding stage, but meeting the growing demand resulting from the swift increase in both the number of inhabitants and the flow of tourists and visitors. If we take the ten coastal municipalities of the central Costa Brava, from Torroella de Montgrí to Santa Cristina d'Aro, the number of hotel establishments rose from 78 in 1956 to 261 in 1968, and the number of beds from 3067 to 14,947, respectively. For the same period, in the archetypal case of Lloret de Mar, the figures rose from 34 to 191 hotel establishments and from 1336 to 12,331 beds, although this figure would reach 25,099 by 1972 [43]. Regarding the supply of potable water, many of the city councils that had implemented their first distribution network during the early decades of the 20th century were forced to expand or strengthen them, especially from the 1950s onwards. Thus, for example, Cadaqués was preparing a new project for its supply network in 1951; Calonge, in 1954; Llançà, in 1955; Castelló d'Empúries, in 1957; Castell-Platja d'Aro, Colera and Lloret de Mar in 1959; Roses, in 1963; Blanes, in 1964; and Tossa de Mar, in 1966. An example of the urgent need to improve the water supply in these towns can be found in May 1956, when the provincial governor of the province, in his capacity as president of the Provincial Tourism Board of Girona, requested that the General Director of Hydraulic Works (Ministry of Public Works) "would deign to order the corresponding technicians to carry out an urgent study of the water supply to the tourist centres on the Coast Brava, as they are suffering from a deficient and inadequate supply" [44]. In the same letter, it was noted that a good part of the coastal municipalities were rural in nature and overwhelmed by the summer influx of tourists. As two possible alternatives, the letter requested that either local groundwater or water from nearby river courses be used.

In addition to improving and expanding the distribution networks in the urban centres, a new type of more complex project began to take shape in which water would be sought from further away and where there was no longer a preference, at least not an exclusive one, for obtaining water from water tables, but from rivers with sufficient flows. Therefore, if in the previous stage the geographical areas of both the supply sources and the distribution network were included within the same technical project due to their proximity, as these began to become more distant from one another the goal of the projects tended to become more individualized and specialized, whether the high-level capture and supply of water or its low-level distribution in the urban centres. High-level refers to supply from the point of capture and low-level the supply to consumers. However, the increase in technical complexity as well as the costly financing of the projects led to the first joint supply proposals; that is, projects covering more than one municipality at a time. The first such case worthy of mention was the 'Project for water supply and distribution in the area of Palafrugell-Begur and their adjacent beaches' (1960). The location of the two urban centres inland from the coast but with numerous beaches in secondary centres such as Llafranc, Calella, Tamariu, Sa Riera, Aiguafreda and Aiguablava meant that the technical and budgetary requirements of this project stretched well beyond any actions carried out previously. The initial proposal was that water would arrive from the Ter River via the main irrigation canal on its right bank; however, this alternative would be reconsidered, at least temporarily, due to the option of obtaining potable water from wells. The works were executed during the second half of the 1960s and were evenly financed between the Hydrographic Confederation of the Eastern Pyrenees and the respective municipalities. Regarding the municipalities on the southern Costa Brava, in 1961 the 
Ministry of Public Works authorized groundwater to be taken from the Tordera River to Lloret de Mar, with a flow rate of 40.8 litres/second; Tossa de Mar received the same authorization in 1973, but with a flow of 100 litres/second. In those cases where the supra-municipal distribution network was effective, associations were created to promote cooperation between municipalities in the provision of services and thus achieve more efficient scales; this was the case with the one created by the municipalities of Palafrugell, Begur, Pals, Regencós and Torrent around 1971 [45].

El Consorci de la Costa Brava (Consortium of the Costa Brava or CCB) was created in 1971 to manage this high-level type of supra-municipal supply interventions and the facilities they required, including catchments, water treatment plants, impulsion pumps and pipes and each municipality's main water storage plant [46]. The Consortium was constituted as a supra-municipal administrative body made up of the Girona Provincial Council, 27 municipalities_-including all of those on the coast of Girona province-and the Hydrographic Confederation of the Eastern Pyrenees (hydraulic administration). It therefore entailed the joint public management of the new water catchments and potable water or treatment plants for a set of neighbouring municipalities. The CCB has been responsible for the economic management of these supply services since then, which includes meeting the costs of project, construction, technical amortization of the facilities, and meeting the costs arising from their operation [37]. With the end of the Franco dictatorship (1975) and the restoration of democracy, a progressive administrative decentralization took place in Spain, awarding more power to the autonomous regions. Therefore, tariff regulations for financing the water supply network came under the control of the competent regional bodies; in the case that concerns us here, La Comissió de Preus de Catalunya (the Prices Committee of Catalonia). The tariffs and prices were, therefore, approved by the Consortium and charged to the municipal water services. In summary, the Consortium "sold" the water to the municipalities, which, in turn, distributed it "down" to the customers of each municipal water service. Final approval of the domestic prices (low-level) was the responsibility of each city council [37]. An added element that would be decisive in view of future supplies to the Costa Brava, including those associated with the Consortium itself, was the entry into service in the 1960s of the three large reservoirs in the province of Girona and its area of influence: Sau (1962) and Susqueda (1968) on the River Ter, and Darnius-Boadella (1969) on the Muga River. In total, they had a storage capacity of $459 \mathrm{hm}^{3}$. However, the fundamental reason why these works were built, located as they were at a distance of between 30 and $60 \mathrm{~km}$ from the nearest coastal areas, was the need to increase and diversify the sources of supply for the urban areas of Barcelona, Girona and Figueres, as well as provide an irrigation supply for the 20,000 hectares comprising the whole of the Empordà plain. It was not until the 1980s that the reservoirs would be incorporated as a real complementary option for the northern Costa Brava (Darnius-Boadella) and central Costa Brava (Sau and Susqueda). The other equally important branch of action pertaining to the CCB since its creation, although beyond the aims of this research, has been the construction and operation of urban wastewater treatment plants. The fact is that it was the tourism boom that ultimately forced it to advance with these projects and turn the Costa Brava into the pioneering area of the Spanish Mediterranean coast with regard to wastewater treatment.

\subsection{Sourcing from the 1980s Onwards: The Incorporation of External Water Resources}

During the 1980s, water consumption in the Costa Brava region reached 460 litres per person per day [47]. Such a high amount left the aquifers over-exploited and had an environmental impact on the groundwater. A clear demonstration of this was the salinization of the water tables and increased conflict between water users-especially in areas such as the lower Muga and the lower Ter-over access to water resources and what at the time became known as "the war of the wells" [48]. During this decade, a fundamental new development with respect to the previous stages was the costly investment made to carry water from the aforementioned large reservoirs to the coast (Table 1). Thus, three main high-level supply points were constructed and supplied from those sources: northern Costa Brava, central Costa Brava and southern Costa Brava. Each of these supply points was set up at a certain 
historical moment and was preceded by individual projects focusing on different situations and problems. Thus, the resulting high-level rates were different in each case. The works were financed by both the CCB and the regional government.

Table 1. Socio-territorial characterization and water supply in the Costa Brava region (years in brackets) for the three defined periods.

\begin{tabular}{|c|c|c|c|}
\hline Parameter & 1st Half 20th C-1950 & 1960-1980 & 1980-Present Day \\
\hline Population (inhabitants) & $59,814(1950)$ & $120,663(1981)$ & $242,280(2017)$ \\
\hline Urbanized surface area $\left(\mathrm{km}^{2}\right)$ & $8.72(1956)$ & $45.90(1980)$ & $64.18(2007)$ \\
\hline Visitors & $622,370(1970)$ & $1,290,934(1980)$ & 4,635,034 (2017) \\
\hline Water consumption $\left(\mathrm{m}^{3}\right)$ & N.A. & $25,424,660(1987)$ & $33,198,030(2012)$ \\
\hline $\begin{array}{l}\text { Water consumption per capita } \\
\text { (litres per person per day) }\end{array}$ & N.A. & 462.10 (1987) & $278.3(2012)$ \\
\hline $\begin{array}{l}\text { Maximum distance to supply } \\
\text { sources }(\mathrm{km})\end{array}$ & $16.00(1950)$ & $16.00(1980)$ & $49.87(2010)$ \\
\hline
\end{tabular}

Source: authors' own data.

High-level supply to the northern Costa Brava began in 1987. It uses the surface waters of the Muga River taken from the Darnius-Boadella Reservoir. The main purpose of this reservoir is to regulate flow rates for agricultural irrigation, which is allocated an average of $25 \mathrm{hm}^{3}$ per year. It also guarantees the supply of water to Figueres $\left(4 \mathrm{hm}^{3} /\right.$ year $)$ and various coastal municipalities such as Roses, Castelló d'Empúries (Empuriabrava), Cadaqués and Llançà ( $5 \mathrm{hm}^{3} /$ year). High-level supply to the central Costa Brava has two functionally different areas. The most northerly one is found in the lower Ter aquifer, and uses wells. It supplies about $3 \mathrm{hm}^{3} /$ year to the municipalities of Palafrugell, Begur, Pals and Regencós. This supply has been managed by the group of municipalities in charge of water for the aforementioned municipalities since the mid-1970s. The southernmost area has been supplied with local resources complemented by surface water from the Ter River (reservoirs) since 1993. It is transported to the coast to provide water to the consortium municipalities of Santa Cristina d'Aro, Sant Feliu de Guíxols, Castell-Platja d'Aro, Calonge and Palamós. This high-level supply takes a clear secondary role to the local water resources. A total of around $6 \mathrm{hm}^{3} /$ year is supplied. Finally, supply to the southern Costa Brava began in 2000 following construction of the potable water plant in Tordera to treat the iron and manganese present in the Tordera aquifer, which affects the catchments for the municipalities of Lloret de Mar and Tossa de Mar. The municipality of Blanes, which also has underground catchments in Tordera, has its own treatment facilities. This aquifer clearly manifested over-exploitation at the beginning of the year 2000, resulting in the Catalan Water Agency (regional water authority) building the first seawater desalination plant in Catalonia. Since 2003, the plant has supplied a total of around $10 \mathrm{hm}^{3}$ to the supply points in Blanes, Lloret de Mar, Tossa de Mar and other municipalities to the north of Barcelona province. The high-level supply managed by the CCB supplies $6 \mathrm{hm}^{3}$ /year to the municipalities of Tossa de Mar and Lloret de Mar [37,46].

In relation to the potable water supply in municipalities on the Costa Brava, it is necessary to bear in mind the pronounced seasonality experienced by tourist demand in this region. According to CCB data for Lloret de Mar, the municipality with the largest hotel capacity and the second largest in demographical terms, from 2001 to 2017 February was the month with the lowest average consumption, with $0.269 \mathrm{hm}^{3}$, while the highest consumption was in August, with $0.798 \mathrm{hm}^{3}$. Therefore, average consumption for the month of August was triple that of February. Furthermore, for the period 1994 to 2017, the municipality of Castell-Platja d'Aro returned similar data, with the month of February having the lowest average consumption $-0.076 \mathrm{hm}^{3}$, and August the highest $-0.256 \mathrm{hm}^{3}$, and average consumption in the month of August again being triple that of February [46]. 


\section{Discussion: From Local and Public Management Models to Regional, International and Private Management}

As a general rule, the three decisive elements that explain water supply expansion in the developed world have been industrialization, urban growth and rising income [40]. In the specific case of the Costa Brava, we should qualify the first component in the sense that it is the tourism industry that has expanded this dynamic. The acceleration experienced in particular during the 1960s and 1970s produced tensions on supply systems that were difficult to manage and often perceived on a strictly local scale. This mainly occurred during the first third of the 20th century, when these systems underwent little expansion. Given the economic and managerial incapacity of the country's municipalities as a whole, the State promoted regulatory measures that would allow water service provision to be outsourced to third parties without losing public ownership. This lack of economic and professional resources especially affected the smaller municipalities. It is not that the state did not invest in hydraulic infrastructures. It did to a great extent, but its focus was essentially on promoting large facilities for storage, capture and distribution, as well as guaranteeing supply for large urban agglomerations. This was not the case with the municipalities on the Costa Brava, all of which had little demographic weight until the consolidation of mass tourism.

With this in mind, the concept of the administrative tender appeared, which produced an increasing amount of legislation, especially in the second half of the 19th century and throughout the twentieth century [49]. There was no single means of managing the potable water supply service. It was therefore legally established as a municipal responsibility, the management of which could either be outsourced or carried out directly by the local authority. Table 2 offers a comparative view of how the variables have behaved for each of the three periods analysed in the previous section: supply infrastructure, financing, administration-operation, resource (water) and environment. This allows us to interpret water governance from the perspective of Political Ecology through the complex interrelations between socioeconomic (mainly the tourism sector), environmental (the use of water resources and its environment) and institutional (the administration and its management) systems.

As we have seen on the previous pages, in the case of the Costa Brava, it was the city councils themselves that assumed the execution and management of embryonic local water supply networks throughout the early decades of the 20th century. This reflects the fact that urban centres were still undeveloped, had supply sources very nearby and still virtually no tourist activity. This was at a time when the complexity of the construction projects and the operating costs were relatively low. The primary purpose was to guarantee a mainly resident population minimum daily allowances, while removing the risk of infectious and parasitic diseases linked to unclean water and the high associated mortality rate, especially in children. The influential hygienist discourse was very much present in many of the projects. Although State action was weak and distant, the first granting of aid was an attempt to alleviate this situation and recognize the chronic lack of clean water that persisted over time. The execution and operation of these first water supply networks was promoted through the creation of municipal public water services owned by the town councils and enacted via promulgation of the Municipal Statute in 1924. The almost total absence of tourism activity means that this could not yet be considered relevant for understanding a specific dynamic with regard to the type of water governance in comparison with that implemented in non-coastal municipalities. We are still talking about a relatively low level of complexity, where there was not yet any differentiation between highand low-level supply systems. 
Table 2. Overview of the main characteristics of supply infrastructures, financing, administration-operation, water resource and the environment throughout the three periods analysed.

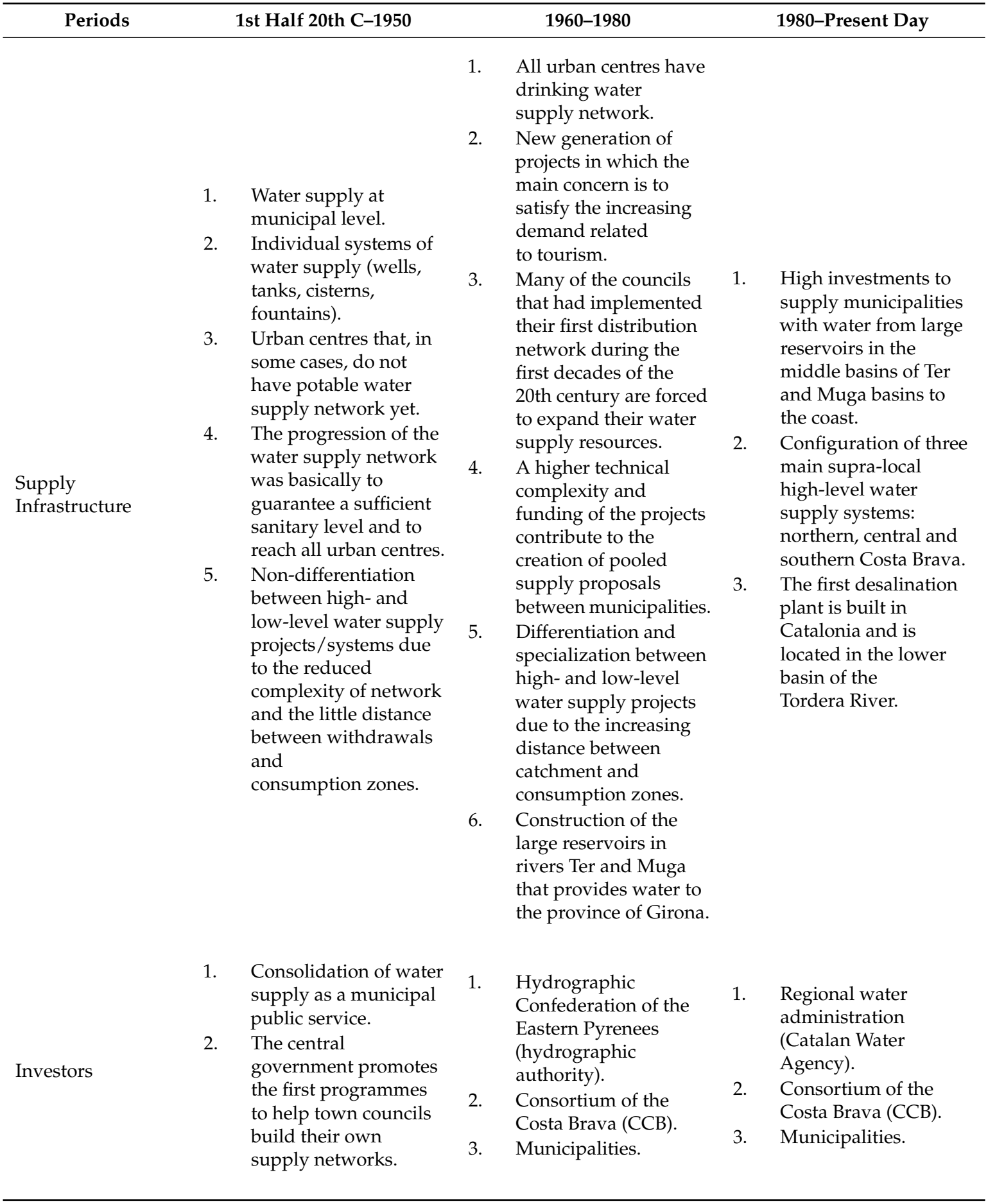


Table 2. Cont.

\begin{tabular}{|c|c|c|c|c|c|c|}
\hline Periods & & 1st Half 20th C-1950 & & 1960-1980 & & 1980-Present Day \\
\hline $\begin{array}{l}\text { Administration } \\
\text { and Operation }\end{array}$ & 1. & $\begin{array}{l}\text { Municipal water } \\
\text { companies and few } \\
\text { private enterprises. }\end{array}$ & 1. & $\begin{array}{l}\text { Configuration of } \\
\text { bodies to promote } \\
\text { cooperation between } \\
\text { councils in the } \\
\text { provision of services } \\
\text { and thus achieve more } \\
\text { efficient scales. } \\
\text { Higher business } \\
\text { expectations for } \\
\text { private companies due } \\
\text { to the increase in } \\
\text { consumers and } \\
\text { invoiced flows related } \\
\text { to tourist activities. } \\
\text { Founding of private } \\
\text { regional companies. } \\
\text { Low-level supply } \\
\text { network management } \\
\text { is mostly delegated to } \\
\text { private companies. }\end{array}$ & 2. & $\begin{array}{l}\text { In low-level supply } \\
\text { systems the tendency } \\
\text { towards privatization } \\
\text { is continued and } \\
\text { reinforced by } \\
\text { budgetary and } \\
\text { financial constraints. } \\
\text { In the high-level } \\
\text { supply systems, } \\
\text { creation of mixed } \\
\text { public-private enterprises } \\
\text { Integration of regional } \\
\text { private companies in } \\
\text { worldwide multinationals }\end{array}$ \\
\hline Water Resource & 1. & $\begin{array}{l}\text { Water resources come } \\
\text { from numerous } \\
\text { underground } \\
\text { withdrawals from local } \\
\text { aquifers close to urban } \\
\text { centres and managed } \\
\text { by each municipality } \\
\text { and provide the proper } \\
\text { volume to satisfy } \\
\text { the demand. }\end{array}$ & 2. & $\begin{array}{l}\text { Local groundwater } \\
\text { resources combined } \\
\text { with flows from } \\
\text { nearby rivers. } \\
\text { First pipelines are } \\
\text { designed connecting } \\
\text { rivers to urban centres. }\end{array}$ & $\begin{array}{l}4 . \\
5 .\end{array}$ & $\begin{array}{l}\text { Incorporation of } \\
\text { external resources } \\
\text { (reservoirs from the } \\
\text { middle basins of rivers } \\
\text { Ter and Muga). } \\
\text { Desalinated water. } \\
\text { Higher } \\
\text { complementarity } \\
\text { between water } \\
\text { resources for supply. } \\
\text { Production of } \\
\text { reclaimed water. } \\
\text { Increased awareness in } \\
\text { water-saving actions. }\end{array}$ \\
\hline Environment & 1. & $\begin{array}{l}\text { Low pressure on } \\
\text { water resources. }\end{array}$ & 1. & $\begin{array}{l}\text { Increasing pressure on } \\
\text { water resources }\end{array}$ & 1. & $\begin{array}{l}\text { Salinization of } \\
\text { groundwater and the } \\
\text { increase of potential } \\
\text { conflicts between } \\
\text { water users. }\end{array}$ \\
\hline
\end{tabular}

However, as investment efforts and technical complexity became more pronounced, the operation and maintenance of the low-level networks (municipal water services) were mostly delegated to private concessionaires. The 1960s saw a turning point in this respect. This dynamic can also be explained by companies being able to expect more business from the increased number of customers and volumes invoiced, whether due to the more than favourable demographic dynamics or the opening of new establishments catering to tourist accommodation (hotels, campsites, etc.), food and drink (restaurants, bars, etc.) or recreational activities. A good example of this is the company SOREA (Sociedad Regional de Abastecimiento de Aguas, SA), founded in 1968. Currently, it is one of the two main concessionaires of low-level water supply and distribution on the Costa Brava. This company initially started out in 1963 as SAUR (Sociedad de Abastecimientos Urbanos y Rurales, SA), co-founded by the Société d'Amenagement Urbain et Rural, based in Paris, and the Sociedad General de Aguas de Barcelona 
(SGAB). The emergence of these companies would not have been possible without the increasing demand for supply on the coast and in the coastal hinterland of Catalonia. Indeed, the SAUR Company placed its focus on the coastal municipalities of the Costa Brava, where it could expect greater business opportunities stimulated by the tourism boom and the "marketing" of water as a fundamental resource catering not only to the expanding housing market but also the recreational activities associated with it. Thus, SAUR took on the first concessions on the Costa Brava in municipalities such as Palafrugell (1964), Begur (1966) and Roses (1967). In relation to these tourist towns, it is worth noting the reflections made by Felipe Mellizo, chief engineer of the Division of Sanitary and River Engineering of the General Directorate of Hydraulic Works (Ministry of Public Works), in 1966: "Towns with a normal population of fewer than 2000 inhabitants must have 30,000 or 40,000 foreign inhabitants during the summer season. So if potable water distribution and waste evacuation must be planned to cater for tourism, its cost represents an initial investment of 10, 20, 30 times greater than it would be otherwise, which no doubt exceeds the municipal and State means, as well as representing an excessive burden on the permanent population. [...] Perhaps the general problem, and especially the one created by seasonal tourist agglomerations, could be fully resolved by accepting private initiatives and, of course, logically, that the State aid extended to private companies as repayable advances with interest does not mean denying a licit and even controlled profit from the sale of potable water and the operation of waste water evacuation and purification systems" [50]. This analysis is very relevant in understanding the transition from the public domain to the private sector in the concession of potable water supply systems in the area of interest. Recent studies, such as those conducted in Andalusia [51], have found that private companies effectively display a preference for those municipalities where the expectations of profit are higher. By way of comparison, in France [52] there is a tendency for local governments to privatize water services when the area in question becomes more complex. In this respect, diverse studies have shown how decisions to delegate the management of municipal services to private companies are based on economies of scale and more specifically when linked to a demographic increase in the area to be supplied [53-55]. In this scenario, the more populated areas tend to gain in levels of specialization and experience and the transaction costs are also lower [56,57].

At this time, the Costa Brava municipalities were being overwhelmed by their growth and the need to tackle the consequences of this as a public administration, both from a professional (technical, administrative staff, etc.) and an economic point of view. The creation of private companies such as those mentioned provided the response that city councils were finding it impossible to give. While this occurred in the sphere of low-level supply, greater demands in the high-level sphere in terms of financing and investment complexity necessitated the creation of new actors, such as the community group of municipalities, which was a public body. A good example is the one created by the municipalities of Palafrugell, Begur, Pals, Regencós and Torrent in 1971. The creation of consortiums of municipalities allowed responsibilities to be transferred to small towns in order to distribute the fixed costs of the service. It also tended to generate a more favourable framework for maximizing economies of scale [58-60]. Sources of supply began to move away from the supply areas and individual municipalities no longer necessarily had their own separate network but could become integrated within a shared one with other larger municipalities. However, private capital was unable to penetrate the sphere of high-level supply. So much so that, after its creation in 1971 and for more than 40 years, the CCB was the main public body in this sphere and had a dual task. On the one hand, consolidating and modernizing the high-level supply network and, on the other, preserving bathing water via the construction of much of the network of wastewater treatment plants that we know today. Without the demands of the tourism sector for high-quality bathing water, all of these investments would certainly have taken much longer to arrive.

The dynamic analysed above shows what some studies call the physical re-scaling of water infrastructure services, as well as their improvement [61,62]. This re-adjustment of the scale involves, on the one hand, a horizontal component such as, for example, the size of the area covered by a uniform institutional structure and/or a physical infrastructure; and secondly, a vertical component, for example, a set of jurisdictions arranged with a different hierarchical level and which is associated 
with the respective institutional and/or physical structure; and finally, a relational element, that is, changes in the vertical and horizontal interactions with other institutional/physical structures and the environment [62]. From this perspective, Thiel analyses the case of the Algarve, on the southern coast of Portugal. Taking the periods defined in our article as a base, it is possible to detect "re-scaling" in this context. It affects supply infrastructures, which are increasingly complex and far reaching, the local, regional and State management institutions behind them, and the physical resource itself (water), with supply sources gradually being sought at greater distances and from multiple sources. This is confirmed when analysing the water governance systems in the Costa Brava region and how they have evolved since the emergence of mass tourism since the middle of the 20th century.

From the environmental perspective, if we focus on the first two historical periods analysed for the Costa Brava (up until the beginning of the 1980s), we observe that environmental considerations carried little weight in the privatization of low-level supply services. The main motivation for the work that was carried out and the services provided by suppliers was to respond to a constantly increasing demand. It was, however, symptomatic that privatizations focused on the type of business operation capable of providing greater expectations of profit, and therefore attracted those types of companies. This happens in areas where potable water is supplied for urban, residential or tourist uses, which are willing to pay more per cubic metre of water consumed. Contrasting with this, in another area of investment of clear environmental significance - that of wastewater-private initiative would not have a presence until the beginning of the 21st century. Indeed, as mentioned above, the Costa Brava Consortium (CCB), a public body created in 1971, exclusively managed the construction and operation of wastewater treatment plants for more than 30 years. Private initiative perceived a sector capable of generating scarce direct economic profit as unattractive during an era when treated wastewater still offered only meagre opportunities for reuse by potential customers. However, it is precisely thanks to the operation of sanitation infrastructures that the hygiene of bathing water, and therefore the use and enjoyment of beaches, can be improved. Without these investments, the Costa Brava would not have witnessed the same progress in terms of tourism and urban growth. Indeed, without wastewater treatment being funded and managed by the public sector, the concessionaire companies that have participated in the privatization of low-level potable water provision would also have had far lower expectations of profit.

The trend towards privatization continued and was reinforced in the latter years of the 20th century and at the beginning of the 21st century, among other things, due to the budgetary and financial restrictions on the city councils, which extended or renewed their concessions with these companies [49]. Of the 22 municipalities analysed that had a private concession, four were due to expire by 2020, four more by 2030 and another four by 2053. According to 2014 data from the regional hydrogeological administration (Catalan Water Agency) and the platform "Aigua es Vida" ("Water is Life"), in 18 of the 22 municipalities considered, which represent $71.42 \%$ of the total population $(175,661$ inhabitants), private companies were concessionaires for the municipal water services. There were, however, only two such companies: SOREA, belonging to the previously mentioned privately-owned AGBAR group (Sociedad General de Aguas de Barcelona or SGAB), with a presence in 12 municipalities and catering to $38.36 \%$ of the population (94,354 inhabitants); and secondly, AQUALIA, belonging to the FCC group (Fomento de Construcciones y Contratas), with a presence in 6 municipalities and catering to $33.06 \%$ of the population $(81,307$ inhabitants). Then there were three municipalities (Mont-ras, Palamós and Blanes), representing 23.92\% of the population (58,837 inhabitants), where the municipal water service was run by a mixed public-private company. In only one municipality (Castelló d'Empúries) was the low-level water management publicly owned and run directly by the city council (4.66\% of the population, with 11,473 inhabitants) (Figure 2). It is during this period that water concession companies grew in scale from regional to multinational. In the case of AGBAR-SGAB, after a friendly public takeover bid in May 2010, the French multinational Suez Environment became the holder of a 75.01\% stake in the company. Previously, in 1992, AGBAR had already joined with SGAB, which was also constituted as a public services 
management group. From that time on, it underwent a swift internationalization process, expanding to countries such as Chile (1999), the United Kingdom (2006), China and Algeria (2007). FCC Aqualia S.A. was created in 1980 with the aim of offering services related to the collection, supply and purification of potable water. It is the mother water management company for the multinational Fomento de Construcciones y Contratas (FCC) and has a presence in 22 countries. Therefore, a clear trend can be identified in the grouping of large transnational corporations aimed at exploitation of the resource, in line with that described by authors such as Finger and Allouche (2002) [63]. In fact, attempts to take advantage of economies of scale by monopolizing the service within a whole region have become a fundamental pillar at European level [64]. In light of the evolution experienced on the Costa Brava and the way in which these corporations have penetrated the various municipalities, it would be plausible to consider a kind of contagion effect among them. Certain authors (Reimer, 1999) [65] have stated that local governments are more likely to privatize a service when other municipalities around them have already taken the same step and have opted to transfer management to a private company. As shown by González-Gómez et al. (2011) [51], there may be two possible explanations for this "contagion effect." On the one hand, the fact that a private company is already providing a local service in a municipality can lead to a commitment to expand the same activity in other neighbouring municipalities [66]. On the other hand, the privatization experience in other neighbouring municipalities can reduce citizen uncertainty and reluctance in the face of a similar decision regarding the management of their own municipal services. This neighbourhood effect has also been found in the case of Spain [55].

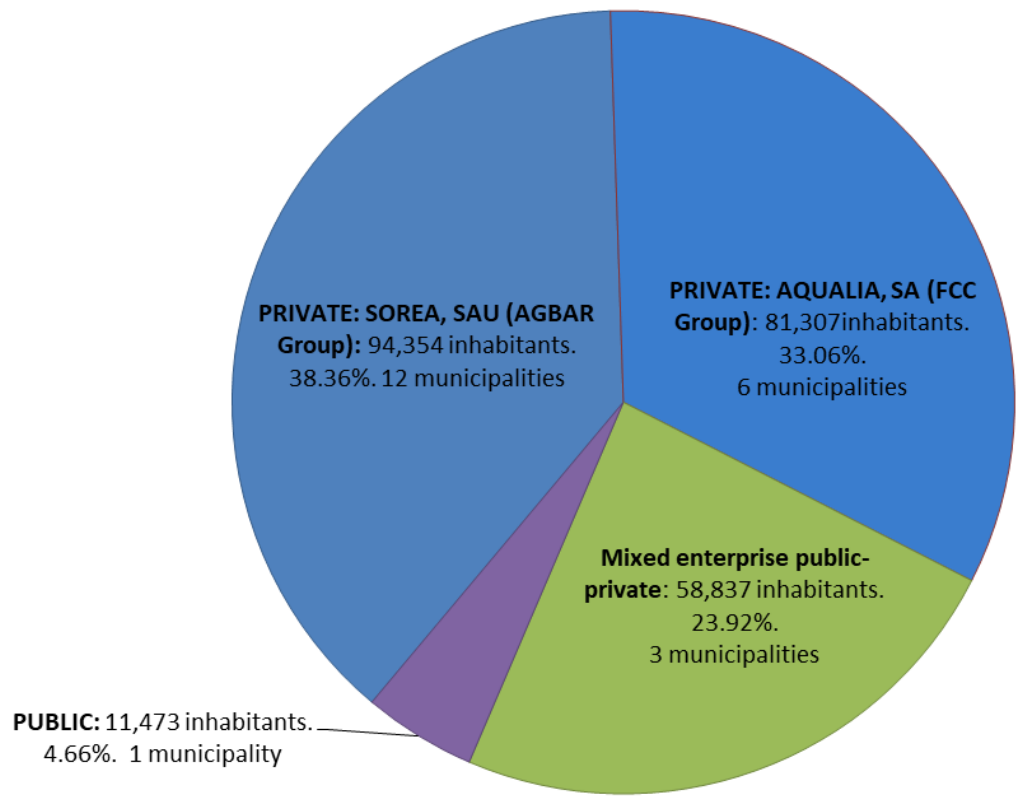

Figure 2. Distribution of ownership of drinking water supply companies in the littoral municipalities in Costa Brava (2014). Source: authors' own data.

The privatization process also reached the high-level water supply system on the Costa Brava, although only partially. Almost 40 years after the founding of the Costa Brava Consortium, a public-private joint venture called ABASTEM was set up in January 2010. It was backed by the Consortium, which held $48 \%$ of the shares, and the two private corporations mentioned earlier, AQUALIA and SOREA, which comprised the largest private shareholder with the remaining 52\%. This business venture was responsible, from that moment on, for managing and guaranteeing the supply of water to the municipalities in the area of study. This mixed management operation came into being four years after the creation of a similar business structure to manage wastewater treatment systems in 2006; prior to that time they had been under the administration of the CCB. The Companyia Mixta d'Aigües de la Costa Brava (Mixed Water Company of the Costa Brava or EMACBSA) was created to this end, with the private partner owning $66.6 \%$ of the shares. These are two examples of 
the varied proliferation of public-private partnerships in the sphere of supply and sanitation that have now spread to most European countries, not only in the Mediterranean, and which are mentioned in a large number of studies [64,67-69]. Regarding the constitution of this type of mixed company in the case of Spanish municipalities, Warner and Bel (2008) have linked their existence to the benefits they receive from both the market contracts and economies of scale available in a monopoly scenario. However, Brooks (1987) [70] conceived mixed-ownership companies as an instrument in the hands of governments to achieve public policy goals. In the Italian case, the creation of mixed companies for the management of water has been commonplace, especially following legislative reforms implemented since 2001, and has been favoured, among other factors, by the wide initial dispersion of existing local operators. In 1993, there were around 23,500 such operators throughout the country [71].

Thus, we find that during this 50-year period (1960-2010), a very large number of privatizations were completed in the supply of high- and low-level potable water and its sanitation in the tourist towns studied. This involved the very notable grouping of businesses and decision centres moving from the local to the regional and, over the last decade, the multinational sphere. This represents the translation of a trend that is widespread in the developed world to a local scale, but with the peculiarity of it affecting one of the leading tourist destinations in the western Mediterranean, the Costa Brava.

\section{Conclusions}

The challenge of supplying potable water to the Costa Brava, especially during the last 70 years, has above all involved coping with the large increase in demand caused by the emergence of mass tourism and demographic and residential expansion. In addition to water being valued as a basic resource to meet immediate human needs, it has come to be perceived as a variable on which the most diverse socioeconomic expectations rely. This has also increased its added value and made the possibility of profits through provision of the quantity and quality required more attractive. Hence the intensified debate in recent years, which can be extrapolated to the international scale, regarding the choice of type of governance-public, communal or private-and the extent to which the urban supply of potable water should be understood as a service or as a business. Even more so given the existence of opposing theories in this debate and a lack of definitive empirical evidence in favour of one management system or another.

In the case of the Costa Brava, there has been an increasingly marked progression towards management formulas that involve concessions to private initiatives in both high- and low-level supply systems. Although in the early days, during the first half of the 20th century, the municipal councils themselves mainly promoted and executed the first local supply networks and operated them directly through the respective municipal water services, this gradually changed over the following decades. Financial, technical and organizational demand to run more complex and costly supply projects gradually resulted in a greater role for private initiatives. Added to this were economic restrictions and a lack of qualified staff, especially in the smaller town councils. This was despite the political context: Spain was promoting interventionism in the field of hydraulic works during the middle decades of the 20th century. The result was increasingly larger companies being set up, attracted by the possibilities of doing business in a consolidated market of users and economies of scale that favoured them. It is an evolution that has remained in place until today and that has even been strengthened as a result of the crisis experienced, in Spain in particular, from 2007 onwards. A historical evolutionary analysis of the area of study has allowed us to detect a transformation from an initial stage with a markedly local system of managing the low-level potable water supply and little involvement of private companies to a current final stage where the supply systems are regional in scale and there is marked prominence in the private sector, dominated by two multinational corporations. These corporations are, in turn, the result of smaller companies being merged; especially from the 1960s onwards, they won the first tenders to manage the low-level potable water supply. That is, they are the companies that marked the starting point for the progressive penetration of private initiative into management of the service. These companies were attracted to the field of business associated with 
higher expectations of profit: low-level water supply to meet residential and tourist demands with a clear capacity for further expansion. In contrast, other less attractive sectors of activity for private capital, such as the wholesale supply network or wastewater treatment, remained under direct public control until fairly recent times. It is specifically in the latter that the environmental component is decisive. Paradoxically, without direct public investment in these sectors, the appropriate conditions for the low-level water supply to continue to be attractive to private initiative would not have formed. It is impossible to imagine that the Costa Brava could have consolidated its tourism position for more than half a century without having bathing waters capable of offering sufficient quality and guaranteed sanitary quality. Without these, the main appeal for visitors, i.e., the beach, would have been lost long ago. This is one component that has gone unjustly unnoticed for all this time.

It is true that advances in technology, materialized in the form of projects, have responded to the growing demand for supply. However, from an environmental perspective, symptoms of fatigue clearly emerged during the 1980s and 1990s, with the overexploitation of the local water resources, basically water tables, and the obligation to travel longer distances to obtain water, not to mention more expensive investments in infrastructure. That said, the implementation of the Water Framework Directive (2000) and the awareness of a more responsible use of the resource, especially after suffering episodes of drought, now point towards greater moderation in consumption. Indeed, there has even been a reduction in consumption, as demonstrated by the latest statistics from the supply companies, in terms of both high- and low-level supply (2010-the present). Policies aimed at reusing the resource through wastewater treatment plants have also helped in this respect [72]. In the case of tourist areas such as the Costa Brava, where water resources are scarce and disputed, the introduction of water-saving devices in hotels and tourist facilities, the establishment of pricing systems that encourage people to save water, environmental awareness campaigns addressed to tourism businesses and visitors, the use of alternative water resources (such as reclaimed water) and the common management of water services are all fundamental to gradually reducing water consumption and to allowing these destinations to survive and develop into the future [73].

A no less relevant challenge and one that will continue in the future is the introduction of public control mechanisms that ensure an equitable balance of the costs involved in the maintenance and operation not only of the supply but also of the purification networks. The Water Framework Directive establishes the principle of cost recovery for water services. However, this issue needs to be treated with caution when costs are transferred to users as a whole. On the other hand, it is essential for good governance that there be clarification regarding the weight awarded to water as a resource for fundamental access or as an object that generates profit and business expectations.

Through this research and its retrospective analysis, we have attempted to identify the main water governance systems that have been implemented on the Costa Brava coast over the last hundred years. This has been done without losing sight of the territorial, socioeconomic and environmental transformations that have led to new scenarios and new actors emerging in the management and exploitation of potable water supply networks. Since it is a tourist destination of international relevance, what has happened on the Costa Brava could be viewed as an example for management in other cases in the Mediterranean region.

Author Contributions: D.P. analysed the evolution of the three different periods and the historical documentation obtained in the archives. He also focused on the discussion and conclusion. A.G.-M. researched the theoretical framework of the subject as is reflected in the first and second sections. Additionally, she introduced the study area. A.R. reviewed different ideas in most of the chapters.

Funding: This research was funded by a program of the Spanish Ministry of Economy and Competitiveness (reference: CSO2013-41262-P). Title of the project: "Analysis of trends and resilience strategies in the uses and consumption of water in tourist spaces. The case of the Costa Brava." Project duration: January 2014-December 2017.

Acknowledgments: The authors appreciate the collaboration of the National Archive of Catalonia (Sant Cugat del Vallès) in order to consult the different historical documentation, especially the water supply projects of the littoral municipalities of the Costa Brava designed throughout the 20th century. 
Conflicts of Interest: The authors declare no conflict of interest.

\section{References}

1. Ajibade, I.; McBean, G. Climate extremes and housing rights: A political ecology of impacts, early warning and adaptation constraints in Lagos slum communities. Geoforum 2014, 55, 76-86. [CrossRef]

2. Nüsser, M. Political ecology of large dams: A critical review. Petermanns Geogr. Mitt. 2003, 147, $20-27$.

3. Tello, E.; Ostos, J.R. Water consumption in Barcelona and its regional environmental imprint: A long-term history (1717-2008). Reg. Environ. Chang. 2012, 12, 347-361. [CrossRef]

4. Cole, S. A political ecology of water equity and tourism. Ann. Tour. Res. 2012, 39, 1221-1241. [CrossRef]

5. Gössling, S. (Ed.) Tourism and Development in Tropical Islands: Political Ecology Perspectives; Edward Elgar Publishing: Cheltenham, UK, 2003; 304p, ISBN 9781843762577.

6. Bujosa, A.; Rosselló, J. Modelling environmental attitudes toward tourism. Tour. Manag. 2007, $28,688-695$. [CrossRef]

7. Deyà, B.; Tirado, D. Hotel water consumption at a seasonal mass tourist destination. The case of the island of Mallorca. J. Environ. Manag. 2011, 92, 2568-2579. [CrossRef] [PubMed]

8. Gössling, S. Global environmental consequences of tourism. Glob. Environ. Chang. 2002, 12, $283-302$. [CrossRef]

9. Gabarda, A.; Ribas, A.; Daunis-i-Estadella, J. Desarrollo turístico y gestión eficiente del agua. Una oportunidad para el turismo sostenible en la Costa Brava (Girona). Investig. Turísticas 2015, 9, 50-69. [CrossRef]

10. Driessen, P.P.J.; Dieperink, C.; van Laerhoven, F.; Runhaar, H.A.C.; Vermeulen, W.J.V. Towards a conceptual framework for the study of shifts in modes of environmental governance-Experiences from The Netherlands. Environ. Policy Gov. 2012, 22, 143-160. [CrossRef]

11. Ricart, S. Improving the management of water multi-functionality through stakeholder involvement in decision-making processes. Util. Policy 2016, 43, 71-81. [CrossRef]

12. Megdal, S.; Eden, S.; Shamir, E. Water governance, stakeholder engagement and sustainable water resources management. Water 2017, 9, 190. [CrossRef]

13. Engle, N.L.; Johns, O.R.; Lemos, M.; Nelson, D.R. Integrated and adaptive management of water resources: Tensions, legacies, and the next best thing. Ecol. Soc. 2011, 16, 19. [CrossRef]

14. Akhmouch, A.; Clavreul, D.; Glas, P. Introducing the OECD Principles on Water Governance. Water Int. 2018, 43, 5-12. [CrossRef]

15. Villar, R. La ecología política urbana: Veinte años de crítica, autocrítica y ampliación de fronteras en el estudio del metabolismo urbano. Documents d'Anàlisi Geogràfica 2017, 63, 173-204. [CrossRef]

16. Beltrán, M.J.; Velázquez, E. The political ecology of water metabolism: The case of the Cobre las Cruces copper mine, southern Spain. Sustain. Sci. 2017, 12, 333-343. [CrossRef]

17. Linton, J.; Budds, J. The hydrosocial cycle: Defining and mobilizing a relational-dialectical approach to water. Geoforum 2014, 57, 170-180. [CrossRef]

18. Swyngedouw, E. The Political Economy and Political Ecology of the Hydro-Social Cycle. J. Contemp. Water Res. Educ. 2009, 142, 56-60. [CrossRef]

19. Tropp, H. Water governance: Trends and needs for new capacity development. Water Policy 2007, 9, 19-30. [CrossRef]

20. Cornea, N.L.; Véron, R.; Zimmer, A. Everyday governance and urban environments: Towards a more interdisciplinary urban political ecology. Geogr. Compass 2017, 11, e12310. [CrossRef]

21. Newman, J. Modernising Governance: New Labour, Policy and Society; SAGE Publications Ltd.: London, UK, 2001; 197p, ISBN 076196990 X.

22. Rogers, P.; Hall, A. Effective Water Governance; TEC Report No. 7; Global Water Partnership: Stockholm, Switzerland, 2003.

23. Tortajada, C. Water Governance: A Research Agenda. Int. J. Water Resour. Dev. 2010, 26, 309-316. [CrossRef]

24. Suárez-Varela, M.; García-Valiñas, M.; González-Gómez, F.; Picazo-Tadeo, A.J. Ownership and Performance in Water Services Revisited: Does Private Management Really Outperform Public? Water Resour. Manag. 2017, 31, 2355-2373. [CrossRef] 
25. González-Gómez, F.; García-Rubio, M.; González-Martínez, J. Beyond the public e private controversy in urban water management in Spain. Util. Policy 2014, 31, 1-9. [CrossRef]

26. Pérard, E. Water supply: Public or private? An approach based on cost of funds, transaction costs, efficiency and political costs. Policy Soc. 2009, 27, 193-219. [CrossRef]

27. Romero, L. Privatització de la gestió de l'aigua i govern del territori a l'arc mediterrani espanyol. Documents d'Anàlisi Geogràfica 2006, 48, 35-59.

28. Bel, G.; Fageda, X. Factors explaining local privatization: A meta-regression analysis. Public Choice 2009, 139, 105-119. [CrossRef]

29. Becker, S.; Beveridge, R.; Naumann, M. Remunicipalization in German cities: Contesting neo-liberalism and reimagining urban governance? Space Polity 2015, 19, 76-90. [CrossRef]

30. Hall, D.; Lobina, E.; Terhorst, P. Re-municipalisation in the early twenty-first century: Water in France and energy in Germany. Int. Rev. Appl. Econ. 2013, 27, 193-214. [CrossRef]

31. Carpintero, S.; Petersen, O. Public-private partnerships (PPPs) in local services: Risk-sharing and private delivery of water services in Spain. Local Gov. Stud. 2016, 42, 958-979. [CrossRef]

32. Carpintero, S.; Petersen, O. Bundling and unbundling in public-private partnerships: Implications for risk sharing in urban transport projects. Proj. Manag. J. 2015, 46, 35-46. [CrossRef]

33. Public Citizen. Public-Public Partnerships a Backgrounder on Successful Water/Wastewater Reengineering Programs. 2002. Available online: https://www.citizen.org/sites/default/files/waterreengineering.pdf (accessed on 15 May 2018).

34. Bakker, K. The Ambiguity of community: Debating alternatives to private-sector provision of urban water supply. Water Altern. 2008, 1, 236-252.

35. Duro, J.A.; Rodríguez, D. Estimació Del PIB Turístic Per Catalunya, Marques i Comarques 2005-2010; Universitat Rovira i Virgili: Tarragona, Spain, 2011; 64p.

36. Martí, C. La Transformació del Paisatge Litoral de la Costa Brava: Anàlisi de L'evolució (1956-2003), Diagnosi de L'estat Actual i Prognosi de Futur. Unpublished Ph.D. Thesis, Universitat de Girona, Girona, Spain, 11 March 2005.

37. Serra, M. La Costa Brava: La gestió integral de l'aigua en zona turística. Nota d'Economia 2009, 93, $183-194$.

38. De Miguel, P. Contaminación y calidad de aguas continentales: El Derecho español ante la normativa de la Comunidad Económica Europea. Revista Española de Derecho Administrativo 1982, 35, 581-611.

39. Simón, I.; Matés, J.M. El abastecimiento de agua potable en México y España: Cambio institucional y aparición de las empresas privadas (1870-1930). In Agua, Territorio y Medio Ambiente: España y América Latina. Políticas Públicas y Participación Ciudadana; Navarro, J.R., Regalado, J., Tortolero, A., Eds.; Universidad de Guadalajara: Guadalajara, Mexico, 2013; pp. 22-54. ISBN 6074507228.

40. Matés, J.M. La regulación del suministro de agua en España: Siglos XIX y XX. Rev. De Hist. Ind. 2016, 61, 15-47.

41. Teixidó, J. Proyecto de Conducción de Aguas Para el Abastecimiento de Blanes (Provincia de Gerona); Arxiu Nacional de Catalunya. Fons 547 (Agència Catalana de l'Aigua); Ayuntamiento de Blanes: Blanes/Girona, Spain, 1925.

42. Rosespèdia. L'enciclopèdia Participativa Del Patrimoni Cultural de Roses. Available online: http:/ / www. rosespedia.cat/index.php/Refer\%C3\%A8ndum_de_1924 (accessed on 9 July 2018).

43. Cals, J. Trenta anys de turisme a la Costa Brava del Baix Empordà. Llibre de la Festa Major de Torroella de Montgrí 1985, 1-6.

44. Llansó de Viñals, J.M. Anteproyecto Del Abastecimiento de Aguas a la Zona de Palafrugell, Bagur y Playas adyacentes. Memoria; Arxiu Nacional de Catalunya. Fons 547 (Agència Catalana de l'Aigua); Confederación Hidrográfica del Pirineo Oriental: Barcelona, Spain, 1959.

45. Latorre, X. Història de l'aigua a Catalunya; L'Abecedari: Premià de Mar, Spain, 1995; 401p, ISBN 8460527204.

46. Consorci de la Costa Brava. Available online: http:/ / www.ccbgi.org/ (accessed on 16 October 2017).

47. Patronat de Turisme Girona Costa Brava (PTGCB). Estudi Estadístic Informàtic de L'índex Ocupacional de la Costa Brava; Diputació de Girona: Girona, Spain, 1988-1996.

48. Genís, N. L'aigua a la Badia de Roses; Consorci de la Costa Brava: Girona, Spain, 1987; 51p.

49. Ruiz-Villaverde, A. Reflexiones sobre la gestión de los servicios urbanos del agua: Un recorrido histórico al caso español. Agua y Territorio Borrador 2013, 1, 31-40. [CrossRef]

50. Mellizo, F. Auxilio del Estado en obras de abastecimiento y saneamiento. Rev. De Obras Públicas 1966, $3017,635-639$. 
51. González-Gómez, F.; Picazo-Tadeo, A.J.; Guardiola, J. Why do local governments privatise the provision of water services? Empirical evidence from Spain. Public Adm. 2011, 89, 471-492. [CrossRef]

52. Carpentier, A.; Nauges, C.; Reynaud, A.; Thomas, A. Effets de la délégation sur le prix de l'eau potable en France: Une analyse à partir de la littérature sur les effets de traitement. Economie et Prévision 2006, 174, 1-19. [CrossRef]

53. Miranda, R. Explaining the privatization decision among local governments in the United States. Res. Urban Policy 1994, 5, 231-274.

54. Greene, J. Cities and Privatization: Examining the Effects of Fiscal Stress, Location, and Wealth in Medium-sized Cities. Policy Stud. J. 1996, 24, 135-144. [CrossRef]

55. Bel, G.; Miralles, A. Factors Influencing Privatization of Urban Solid Waste Collection in Spain. Urban Stud. 2003, 40, 1323-1334. [CrossRef]

56. Nelson, M. Municipal government approaches to service delivery: An analysis from a transaction cost perspective. Econ. Inq. 1997, 35, 82-96. [CrossRef]

57. Hefetz, A.; Warner, M. Beyond the market versus Planning Dichotomy: Understanding privatisation and its reverse in US cities. Local Gov. Stud. 2007, 33, 555-572. [CrossRef]

58. Warner, M.E.; Hebdon, R. Local government restructuring: Privatization and its alternatives. J. Policy Anal. Manag. 2001, 20, 315-336. [CrossRef]

59. Warner, M.E.; Hefetz, A. Rural-urban differences in privatization: Limits to the competitive state. Environ. Plan. C Gov. Policy 2003, 21, 703-718. [CrossRef]

60. Bel, G.; Hebdon, R.; Warner, M. Local government reform: Privatisation and its alternatives. Local Gov. Stud. 2007, 33, 507-515. [CrossRef]

61. Howitt, R. Scale. In A Companion to Political Geography; Agnew, J., Mitchell, K., Gerard, T., Eds.; Blackwell Publishing: Oxford, UK, 2003; 494p, ISBN 9780631220312.

62. Thiel, A. Constructing a strategic, national resource: European policies and the up-scaling of water services in the Algarve (Portugal). Environ. Manag. 2010, 46, 44-59. [CrossRef] [PubMed]

63. Finger, M.; Allouche, J. Water Privatization: Trans-National Corporations and the Re-Regulation of the Wàter Industry; Spon Press: London, UK; New York, NY, USA, 2002; 272p, ISBN 0-415-23208-2.

64. Warner, M.E.; Bel, G. Competition or monopoly? Comparing privatization of local public services in the US and Spain. Public Adm. 2008, 86, 723-735. [CrossRef]

65. Reimer, S. 'Getting by' in time and space: Fragmented work in local authorities. Econ. Geogr. 1999, 75, 157-177. [CrossRef]

66. Donahue, J. The Privatization Decision: Public Ends, Private Means; Basic Books: New York, NY, USA, 1989; ISBN 0465063586.

67. Barraqué, B. Past and future sustainability of water policies in Europe. Nat. Resour. Forum 2003, $27,200-211$. [CrossRef]

68. Kallis, G.; Coccossis, H. Water for the city: Lessons from tendencies and critical issues in five advanced metropolitan areas. Built Environ. 2002, 28, 96-110.

69. Bithas, K. The European policy on water use at the urban level in the context of the water framework directive effectiveness, appropriateness and efficiency. Eur. Plan. Stud. 2008, 16, 1293-1311. [CrossRef]

70. Brooks, S. The mixed ownership corporation as an instrument of public policy. Comp. Politics 1987, 19, 173-191. [CrossRef]

71. Asquer, A. Explaining the partial privatization of public service provision: The emergence of mixed ownership water firms in Italy (1994-2009). In Proceedings of the Fifth Annual Conference of Competition and Regulation in Network Industries, Brussels, Belgium, 30 November 2012; Available online: https: / / ssrn.com/abstract=2235585 (accessed on 16 July 2018). 
72. Gabarda, A.; Fraguell, R.M.; Pavón, D.; Ribas, A. Tourist Development and wastewater treatment in the Spanish Mediterranean Coast: The Costa Brava case study. Int. J. Sustain. Dev. Plan. 2016, 11, 245-254. [CrossRef]

73. Gabarda, A.; Ribas, A. Understanding reductions in water consumption in tourist areas: A case study of the Costa Brava, Spain. Int. J. Water Resour. Manag. 2016, 32, 912-930. [CrossRef] 